\title{
Haemophilus segnis polymicrobial and monomicrobial bacteraemia identified by $16 S$ ribosomal RNA gene sequencing
}

\author{
SUSANNA KAR-PUI LAU, PATRICK CHIU-YAT WOO, BENEDICT YIN-LEUNG CHAN, \\ AMI MEI-YUK FUNG, TAK-LUN QUE and KWOK-YUNG YUEN
}

Department of Microbiology, University of Hong Kong, Queen Mary Hospital, and Department of Microbiology, Tuen Mun Hospital, Hong Kong

This paper reports a case of Haemophilus segnis polymicrobial bacteraemia and a case of $H$. segnis monomicrobial bacteraemia identified by $16 \mathrm{~S}$ ribosomal RNA gene sequencing. In the first case, a gram-negative aerobic coccobacillus was isolated with Streptococcus intermedius and $S$. sanguis from the blood culture of a 32-year-old intravenous drug addict with left thoracic empyema. In the second case, a gram-negative aerobic coccobacillus was isolated from the blood culture of an 82-year-old woman with Clostridium difficile colitis and septicaemic shock. Both gram-negative coccobacilli grew on chocolate agar as colonies of $1 \mathrm{~mm}$ in diameter after incubation for $24 \mathrm{~h}$ at $37^{\circ} \mathrm{C}$ in air with $\mathrm{CO}_{2} 5 \%$, but only to pinpoint sizes on blood agar under the same incubation conditions. Both strains were factor V-dependent, but not factor X-dependent. For the first isolate, the Vitek system (NHI) showed that it was $56 \%$ likely to be Actinobacillus actinomycetemcomitans and 40\% Neisseria subflava; whereas the API system (NH) showed that it was $58 \%$ likely to be $H$. aphrophilus/paraphrophilus and $42 \% H$. parainfluenzae. For the second isolate, the Vitek system (NHI) showed that it was $95 \%$ likely to be $H$. influenzae VIII; whereas the API system (NH) showed that it was $58 \%$ likely to be $H$. aphrophilus/paraphrophilus and $42 \% H$. parainfluenzae. 16S rRNA gene sequencing showed that there were four base differences between isolate 1 and $\mathrm{H}$. segnis and two base differences between isolate 2 and $H$. segnis, indicating that both isolates most closely resembled a strain of $H$. segnis. Only two cases of $H$. segnis bacteraemia were found in the English scientific literature, one in a case of infective endocarditis and the other in a case of pancreatic abscess. Including the present two cases, the overall mortality of $H$. segnis bacteraemia was $50 \%$.

\section{Introduction}

Haemophilus species, other than $H$. influenzae, have been considered uncommon causes of human disease. H. segnis, in particular, is rarely reported as being a pathogen. Infections reported to be associated with $H$. segnis include periodontal disease, infective endocarditis, acute cholecystitis, acute appendicitis and pancreatic abscess, amongst which $H$. segnis bacteraemia was reported only in a case of infective endocarditis and a case of pancreatic abscess [1-5]. Haemophilus spp. are traditionally identified on the

Received 29 June 2001; revised version received 2 Jan. 2002; accepted 9 Jan. 2002.

Corresponding author: Dr K-Y. Yuen (e-mail: hkumicro@, hkucc.hku.hk). basis of growth factor requirement, $\mathrm{CO}_{2}$ dependence, haemolysis, enzymic activities and sugar fermentation. However, these biochemical tests may result in ambiguous biochemical profiles and give inconclusive results [5-7].

Since the introduction of PCR and DNA sequencing, comparison of the gene sequences of bacterial species has shown that the 16S ribosomal RNA (rRNA) gene is highly conserved within a species and among species of the same genus. Phylogenetic trees, based on base differences between species, are constructed from $16 \mathrm{~S}$ rRNA gene sequences; and bacteria are classified and re-classified into new genera $[8,9]$. Furthermore, noncultivable organisms and organisms with ambiguous biochemical profiles can be classified and identified $[10,11]$. Recent reports described the application of 
$16 \mathrm{~S}$ rRNA gene sequencing in the identification of clinical isolates with ambiguous biochemical profiles [12-17] and a bacterium that was non-cultivable [18]. This article reports a case of $H$. segnis polymicrobial bacteraemia and a case of $H$. segnis monomicrobial bacteraemia identified by $16 \mathrm{~S}$ rRNA gene sequencing. Other infections associated with $H$. segnis are also reviewed.

\section{Materials and methods}

\section{Patients and microbiological methods}

All clinical data were collected prospectively as described previously [19]. Clinical specimens were collected and handled according to standard protocols, and all suspect colonies were identified by standard conventional biochemical methods [20]. The Vitek System (NHI) (bioMérieux Vitek, Hazelwood, MO, USA) and API system (NH) (bioMérieux Vitek) were also used for the biochemical identification of the bacterial isolates in this study.

\section{DNA extraction, PCR amplification and sequencing of $16 S$ rRNA genes}

Bacterial DNA extraction and PCR amplification and DNA sequencing of the 16S rRNA genes were performed as described previously $[12-15,21]$. 5'AGTTTGATCCTGGCTCAG-3' (LPW55) and 5'-AG GCCCGGGAACGTATTCAC-3' (LPW56) were used as the PCR primers and LPW55, LPW56, 5'-AGCAC CGGCTAACTCCGT-3' (LPW69) and 5'-TAATCCT GTTTGCTCCCCAC-3' (LPW106) were used as the sequencing primers. The sequences of the PCR products were compared with known 16S rRNA gene sequences in the GenBank database by BLAST searches and multiple sequence alignment was performed with the CLUSTAL W program [22]. The phylogenetic tree was constructed by the neighbourjoining method with GrowTree (Genetics Computer Group). A total of 1393 nucleotide positions was included in the analysis.

\section{Results}

\section{Patients and identification of the bacterial isolates by conventional methods and commercially available systems}

Case 1. A 32-year-old Chinese intravenous drug addict was admitted to hospital because of progressive shortness of breath and left pleuritic chest pain for 1 week. His past medical history was unremarkable. His oral temperature was $38^{\circ} \mathrm{C}$. Chest X-ray showed left hydro-pneumothorax. Total white cell count was $21.3 \times 10^{9} / \mathrm{L}$, with neutrophils $17.8 \times 10^{9} / \mathrm{L}$, lymphocytes $1.1 \times 10^{9} / \mathrm{L}$ and monocytes $1.5 \times 10^{9} / \mathrm{L}$. The haemoglobin level was $7.5 \mathrm{~g} / \mathrm{dl}$ and the platelet count was $457 \times 10^{9} / \mathrm{L}$. Blood culture was performed and the patient was treated empirically with intravenous ticarcillin/clavulanate and gentamicin. A chest drain was inserted and $1500 \mathrm{ml}$ of pus with air was drained. The pus was sent for gram's smear and bacterial culture. Echocardiogram did not show evidence of infective endocarditis. The patient recovered after treatment with intravenous antibiotics for 6 weeks.

On day 1 of incubation, the aerobic blood culture bottle was positive with gram-positive cocci in chains and gram-negative coccobacilli. The gram-positive cocci were identified as Streptococcus intermedius and $S$. sanguis. The gram-negative coccobacillus grew on chocolate agar to give colonies of $1 \mathrm{~mm}$ in diameter after incubation for $24 \mathrm{~h}$ at $37^{\circ} \mathrm{C}$ in air with $\mathrm{CO}_{2} 5 \%$, but only to pinpoint sizes on blood agar under the same incubation conditions. The strain was factor V-dependent, but not factor X-dependent. The Vitek system (NHI) showed that it was $56 \%$ likely to be Actinobacillus actinomycetemcomitans and 40\% Neisseria subflava; whereas the API system $(\mathrm{NH})$ showed that it was $58 \%$ likely to be $H$. aphrophilus/paraphrophilus and $42 \%$ H. parainfluenzae (Table 1). The strain was $\beta$-lactamase-negative and sensitive to ampicillin, cefotaxime, imipenem, co-trimoxazole and chloramphenicol. Gram's smear of the empyema pus showed leucocytes +++ , gram-negative coccobacilli and gram-positive cocci in chains. However, only a Bacteroides sp. was isolated on culture.

Case 2. An 82-year-old Chinese woman was admitted to hospital because of lower abdominal pain and diarrhoea for 1 day. Her past history was unremarkable except for an episode of gastro-enteritis 2 weeks previously, which was treated with intravenous cefuroxime. Upon transfer, she was afebrile. Examination revealed lower abdominal tenderness with guarding and rebound tenderness. Abdominal X-ray did not show any significant abnormality. Total white cell count was $50.2 \times 10^{9} / \mathrm{L}$, with neutrophils $44.2 \times 10^{9} / \mathrm{L}$, lymphocytes $4.5 \times 10^{9} / \mathrm{L}$ and monocytes $1.5 \times 10^{9} / \mathrm{L}$. Haemoglobin level was $13.5 \mathrm{~g} / \mathrm{dl}$ and platelet count $438 \times 10^{9} / \mathrm{L}$. Serum urea was $15.1 \mathrm{mmol} / \mathrm{L}$ and creatinine $219 \mu \mathrm{mol} / \mathrm{L}$. Liver enzymes were normal. Blood culture was performed and stool was sent for culture and Clostridium difficile cytotoxin detection. Empirical intravenous cefoperazone/sulbactam was administered. She rapidly went into septicaemic shock and died despite attempted resuscitation.

On day 1 of incubation, the aerobic blood culture bottle was positive with a gram-negative aerobic coccobacillus. The bacterium grew on chocolate agar to give colonies of $1 \mathrm{~mm}$ in diameter after incubation for $24 \mathrm{~h}$ at $37^{\circ} \mathrm{C}$ in air with $\mathrm{CO}_{2} 5 \%$, but only to pinpoint sizes on blood agar under the same incubation conditions. The strain was factor V-dependent, but not factor Xdependent. The Vitek system (NHI) showed that it was $95 \%$ likely to be $H$. influenzae VIII; whereas the API system $(\mathrm{NH})$ showed that it was $58 \%$ likely to be $H$. 
Table 1. Biochemical profile and identification of the blood culture isolates by Vitek system (NHI) and API system $(\mathrm{NH})$

\begin{tabular}{|c|c|c|c|c|}
\hline \multirow{2}{*}{$\begin{array}{l}\text { Biochemical } \\
\text { reactions/enzymes/substrates }\end{array}$} & \multicolumn{2}{|c|}{ Case 1} & \multicolumn{2}{|c|}{ Case 2} \\
\hline & Vitek NHI & API NH & Vitek NHI & API NH \\
\hline Phenylphosphonate & - & & + & \\
\hline Proline arylamidase & - & - & - & - \\
\hline$\gamma$-Glutamyl-arylamidase & - & - & - & - \\
\hline Glycine arylamidase & - & & - & \\
\hline Lysine arylamidase & + & & + & \\
\hline$\beta$-Galactosidase & - & - & - & - \\
\hline Indole production & - & - & - & - \\
\hline Phosphate choline & - & & + & \\
\hline \multicolumn{5}{|l|}{ Acidification of } \\
\hline glucose & + & + & + & + \\
\hline fructose & & + & & + \\
\hline sucrose & - & & - & \\
\hline maltose & + & + & + & + \\
\hline saccharose & & + & & + \\
\hline Reduction of triphenyl tetrazolium & - & & - & \\
\hline Resazurin & - & & - & \\
\hline Ornithine decarboxylase & - & - & - & - \\
\hline Lipase & & - & & - \\
\hline Alkaline phosphatase & & + & & + \\
\hline Urease & - & - & - & - \\
\hline Penicillinase & - & - & - & - \\
\hline Identification & $\begin{array}{l}56 \% \text { A. actino- } \\
\text { mycetemcomitans } \\
40 \% \text { N. subflava }\end{array}$ & $\begin{array}{c}58 \% \text { H. aphrophilus/ } \\
\text { paraphrophilus } \\
42 \% \text { H. parainfluenzae }\end{array}$ & $\begin{array}{l}95 \% \text { H. influenzae } \\
\text { VIII }\end{array}$ & $\begin{array}{c}58 \% \text { H. aphrophilus/ } \\
\text { paraphrophilus } \\
42 \% \text { H. parainfluenzae }\end{array}$ \\
\hline
\end{tabular}

aphrophilus/paraphrophilus and $42 \% H$. parainfluenzae (Table 1). The strain was $\beta$-lactamase-negative, and sensitive to ampicillin, cefotaxime, imipenem, cotrimoxazole, and chloramphenicol. Stool tests for $C$. difficile culture and cytotoxin were both positive.

\section{S rRNA gene sequencing}

PCR of the 16S rRNA genes of the two isolates showed bands at $1393 \mathrm{bp}$. There were four base differences between blood culture isolate 1 and $H$. segnis (GenBank accession no. AF300472), and two base differences between blood culture isolate 2 and $H$. segnis (GenBank accession no. AF300472), indicating that both isolates most closely resembled a strain of H. segnis (Fig. 1).

\section{Discussion}

$H$. segnis was proposed as one of the factor Vdependent Haemophilus species by Kilan and Schiott in 1975 and Kilan in 1976, and was formally published in the International Journal of Systematic Bacteriology in 1977 [23]. This organism has been isolated from dental plaque and the human oropharynx. It is rarely reported as being a pathogen, but has been associated with periodontal disease and occasionally with serious infections including infective endocarditis, acute cholecystitis, acute appendicitis and pancreatic abscess (Table 2) [1-5]. An overall review of $H$. segnis infection showed a male:female ratio of 7:4. Most patients were young (median age 29 years). Only two patients had possible predisposing factors. One was a chronic alcoholic (case 9) and the other an intravenous drug addict (case 10). Acute appendicitis was the commonest clinical condition associated with isolation of $H$. segnis (cases 3-8) and peritoneal fluid was the commonest site for isolation of this organism (cases 3-7). Only two cases of $H$. segnis bacteraemia were found in the English scientific literature (MEDLINE Search 1966-2001), one in a case of infective endocarditis (case 1) and the other in a case of pancreatic abscess (case 9) [1,5]. Including the present two cases, the overall mortality of $H$. segnis bacteraemia was $50 \%$, whereas infections without bacteraemia were all cured with treatment (Table 2).

The route of infection in previous reports of $H$. segnis infection was largely uncertain, although the oropharynx was proposed to be the source in all cases [1-5]. In the first case in the present study, it is likely that the patient had an aspiration pneumonia complicated by empyema and secondary bacteraemia, because the two concomitant isolates from blood culture, $S$. intermedius and $S$. sanguis, are both commensals of the oropharynx. Gram's smear of the empyema pus showed gram-negative coccobacilli and gram-positive cocci in chains, but only a Bacteroides sp. was isolated on culture. This can be explained by prior administration of antibiotics before the thoracocentesis. In the second case, the lady had $C$. difficile colitis and died of septicaemic shock. $H$. segnis was isolated from her blood. We speculate that the bacterium gained access to the bloodstream through the inflamed bowel mucosa. Although $H$. segnis has not been isolated from the 


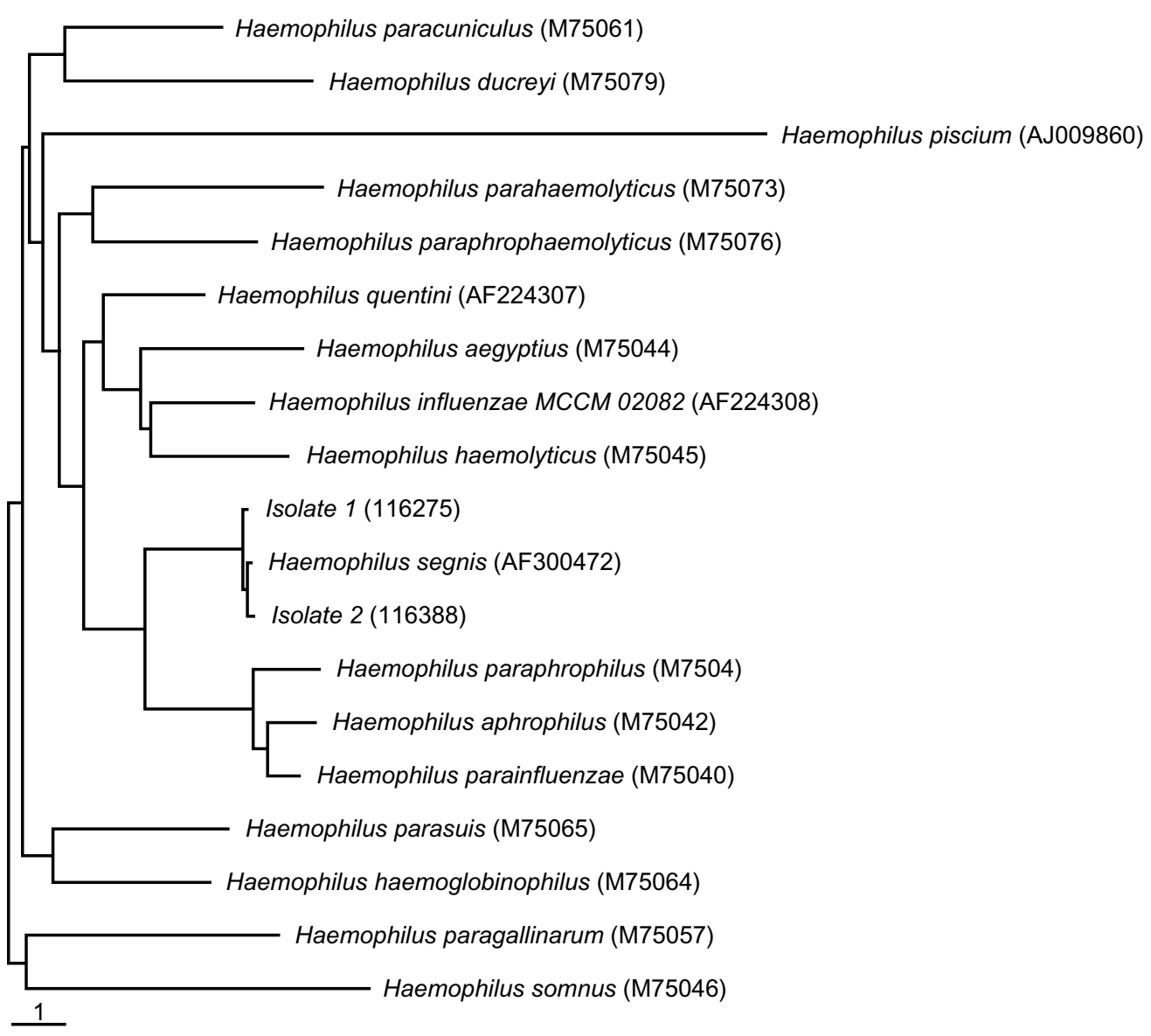

Fig. 1. Phylogenetic tree showing the relationship of isolates 1 and 2 to the other Haemophilus spp., A. actinomycetemcomitans and $N$. subflava. The tree was inferred from $16 \mathrm{~S}$ rRNA sequence data by the neighbour-joining method. The scale bar indicates the number of substitutions per 100 bases estimated with the Jukes-Cantor correction. Names and accession nos are given as cited in the GenBank database. A total of 1393 nucleotide positions was included in the analysis.

lower gastrointestinal tract, its unexplained association with gastrointestinal tract infection suggests that it may occasionally colonise the gut. In three cases of $H$. segnis appendicitis, concomitant isolates from the peritoneal fluid were commensals of the lower gastrointestinal tract (Table 2, cases 5-7) [4] and Haemophilus spp. have been found to be members of the faecal flora [24, 25]. Further investigations are needed to delineate the relationship between $H$. segnis and gastrointestinal tract disease.

16S rRNA gene sequencing is useful for the identification of $H$. segnis. Identification of $H$. segnis by conventional biochemical tests has been difficult. $H$. segnis is a fastidious organism and is differentiated from other Haemophilus spp. primarily by its generally negative biochemical reactions (the Latin adjective segnis means sluggish) [23]. However, these tests may give inconclusive results. In the reported cases of $H$. segnis infection, all clinical isolates required confirmation of identity by reference laboratories (Table 2) [1-5]. Haemophilus spp. that are factor V- but not factor X-dependent include $H$. segnis, $H$. paraphrophilus, $H$. parainfluenzae and $H$. parahaemolyticus, of which $H$. paraphrophilus is $\mathrm{CO}_{2}$-dependent and
$H$. parahaemolyticus is haemolytic. $H$. segnis is phenotypically very similar to $H$. parainfluenzae and many clinical laboratories report all Haemophilus spp. that are factor $\mathrm{V}$ - but not factor $\mathrm{X}$-dependent as $H$. parainfluenzae [7]. In a case of pancreatic abscess, the pathogen was reported initially as $H$. parainfluenzae and was only subsequently confirmed to be $H$. segnis by a reference laboratory (Table 2, case 9) [5]. It is possible that the true prevalence of $H$. segnis infection has been underestimated. The application of $16 \mathrm{~S}$ rRNA gene sequencing for identification of $H$. parainfluenzae has been described in two cases of infective endocarditis, where identification by conventional techniques was difficult. In one case, the isolate was identified presumptively as $H$. parainfluenzae by its factor $\mathrm{V}$ dependency and biochemical reactions, but other phenotypic characteristics were atypical [6]. In the other case, the blood culture isolate was identified preliminarily by the clinical microbiological laboratory as a strain of $A$. actinomycetemcomitans [7]. Interestingly, the blood culture isolate in the first case in the present study was also identified by the Vitek (NHI) system as $56 \%$ likely to be $A$. actinomycetemcomitans, which is phylogenetically closely related to $H$. parainfluenzae, H. paraphrophilus, $H$. aphrophilus and $H$. 
Table 2. Serious H. segnis infections reported in the English scientific literature

\begin{tabular}{|c|c|c|c|c|c|c|c|c|c|}
\hline $\begin{array}{l}\text { Case } \\
\text { no. }\end{array}$ & Reference & $\begin{array}{l}\text { Sex/age } \\
\text { (y) }\end{array}$ & $\begin{array}{l}\text { Underlying } \\
\text { diseases }\end{array}$ & Site of isolation & Method of identification & $\begin{array}{l}\text { Concomitant } \\
\text { isolates }\end{array}$ & Diagnosis & Treatment & Outcome \\
\hline 1 & 1 & $\mathrm{~F} / 76$ & None & Blood & $\begin{array}{l}\text { Confirmed by Royal Dental College, } \\
\text { Aarhus, Denmark }\end{array}$ & None & Infective endocarditis & Ampicillin + netilmicin & Cured \\
\hline 2 & 2 & $\mathrm{~F} / 58$ & None & Gallbladder & $\begin{array}{l}\text { RapID NH system, confirmed by Illinois } \\
\text { Department of Public Health }\end{array}$ & None & Acute cholecystitis & Cholecystectomy, cephazolin & Cured \\
\hline 3 & 3 & $\mathrm{M} / 24$ & NA & Peritoneal fluid & Confirmed by $\mathrm{CDC}$ & None & Acute appendicitis & Appendicectomy, imipenem & Cured \\
\hline 4 & 3 & $\mathrm{M} / 27$ & NA & Peritoneal fluid & Confirmed by CDC & None & Acute appendicitis & Appendicectomy, cefoxitin & Cured \\
\hline 5 & 3 & $\mathrm{M} / 18$ & NA & Peritoneal fluid & Confirmed by CDC & Bacteroides multiacidus & Acute appendicitis & Appendicectomy, cefoxitin & Cured \\
\hline 6 & 3 & $\mathrm{M} / 22$ & None & Peritoneal fluid & Confirmed by CDC & $\begin{array}{l}\text { Escherichia coli } \\
\text { Klebsiella pneumoniae }\end{array}$ & Acute appendicitis & $\begin{array}{l}\text { Appendicectomy, cefoxitin } \\
\rightarrow \text { Ampicillin }+ \text { clindamycin } \\
+ \text { tobramycin } \rightarrow \text { cefoxitin }\end{array}$ & Cured \\
\hline 7 & 3 & $\mathrm{M} / 32$ & None & Peritoneal fluid & Confirmed by CDC & $\begin{array}{l}\text { Bacteroides sp. } \\
\text { Lactobacillus } \mathrm{sp} . \\
\text { Peptostreptococcus sp. } \\
\text { Propionibacterium sp. }\end{array}$ & Acute appendicitis & Appendicectomy, cefoxitin & Cured \\
\hline 8 & 4 & $\mathrm{~F} / 18$ & None & Appendix tip & $\begin{array}{l}\text { Confirmed by Central Public Health } \\
\text { Laboratory, Colindale, London }\end{array}$ & None & Acute appendicitis & $\begin{array}{l}\text { Appendicectomy, } \\
\text { cephradine + gentamicin } \\
\text { + metronidazole }\end{array}$ & Cured \\
\hline 9 & 5 & $\mathrm{M} / 29$ & Alcoholism & $\begin{array}{l}\text { Blood, } \\
\text { pancreas }\end{array}$ & $\begin{array}{l}\text { Initially identified as Haemophilus } \\
\text { parainfluenzae, subsequently identified } \\
\text { as Haemophilus segnis by National Type } \\
\text { Culture Collection }\end{array}$ & None & Pancreatic abscess & $\begin{array}{l}\text { Surgical drainage, } \\
\text { ampicillin + gentamicin } \\
\quad+\text { metronidazole }\end{array}$ & Died \\
\hline 10 & $\begin{array}{l}\text { Present } \\
\text { study, } \\
\text { case } 1\end{array}$ & $\mathrm{M} / 32$ & $\begin{array}{l}\text { Intravenous drug } \\
\text { addict }\end{array}$ & Blood & 16S rRNA gene sequencing & $\begin{array}{l}\text { Streptococcus milleri } \\
\text { Streptococcus sanguis }\end{array}$ & Empyema thoracis & $\begin{array}{l}\text { Drainage, ticarcillin/ } \\
\text { clavulanate + gentamicin }\end{array}$ & Cured \\
\hline 11 & $\begin{array}{l}\text { Present } \\
\text { study, } \\
\text { case } 2\end{array}$ & $\mathrm{~F} / 82$ & None & Blood & 16S rRNA gene sequencing & None & $\begin{array}{l}\text { Bacteraemia due to } \\
\text { Clostridium difficile } \\
\text { colitis }\end{array}$ & Cefoperazone/sulbactam & Died \\
\hline
\end{tabular}


segnis (Fig. 1). In fact, it has been proposed that $A$. actinomycetemcomitans should probably be reclassified as a species of Haemophilus [26, 27].

This work was partly supported by the University Development Fund, University Research Grant Council and the Committee of Research and Conference Grants, University of Hong Kong.

\section{References}

1. Bangsborg JM, Tvede M, Skinhøj P. Haemophilus segnis endocarditis. $J$ Infect 1988; 16: 81-85.

2. Carson HJ, Rezmer S, Belli J. Haemophilus segnis cholecystitis: a case report and literature review. $J$ Infect 1997; 35 85-86.

3. Namnyak SS, Martin DH, Ferguson FD, Chiquito PE, Hughes DF. Haemophilus segnis appendicitis. J Infect 1991; 23: $339-341$.

4. Welch WD, Southern PM, Schneider NR. Five cases of Haemophilus segnis appendicitis. J Clin Microbiol 1986; 24: $851-852$.

5. Bullock DW, Devitt PG. Pancreatic abscess and septicaemia caused by Haemophilus segnis. J Infect 1981; 3: 82-85.

6. Das I, DeGiovanni JV, Gray J. Endocarditis caused by Haemophilus parainfluenzae identified by $16 \mathrm{~S}$ ribosomal RNA sequencing. J Clin Pathol 1997; 50: 72-74.

7. Hamed KA, Dormitzer PR, Su CK, Relman DA. Haemophilus parainfluenzae endocarditis: application of a molecular approach for identification of pathogenic bacterial species. Clin Infect Dis 1994; 19: 677-683.

8. Olsen GJ, Woese CR. Ribosomal RNA: a key to phylogeny. FASEBJ 1993; 7: 113-123.

9. Olsen GJ, Overbeek R, Larsen N et al. The ribosomal database project. Nucleic Acids Res Suppl 1992; 20: 2199-2200.

10. Relman DA, Loutit JS, Schmidt TM, Falkow S, Tompkins LS. The agent of bacillary angiomatosis. An approach to the identification of uncultured pathogens. N Engl J Med 1990; 323: $1573-1580$.

11. Relman DA, Schmidt TM, MacDermott RP, Falkow S. Identification of the uncultured bacillus of Whipple's disease. $N$ Engl J Med 1992; 327: 293-301.

12. Woo PCY, Leung ASP, Leung KW, Yuen K. Identification of slide coagulase positive, tube coagulase negative Staphylococcus aureus by $16 \mathrm{~S}$ ribosomal RNA gene sequencing. J Clin Pathol: Mol Pathol 2001; 54: 244-247.

13. Woo PCY, Cheung EY, Leung K, Yuen K. Identification by $16 \mathrm{~S}$ ribosomal RNA gene sequencing of an Enterobacteriaceae species with ambiguous biochemical profile from a renal transplant recipient. Diagn Microbiol Infect Dis 2001; 39: 8593.
14. Woo PCY, Tsoi H-W, Leung K-W et al. Identification of Mycobacterium neoaurum isolated from a neutropenic patient with catheter-related bacteremia by $16 \mathrm{~S}$ ribosomal RNA sequencing. J Clin Microbiol 2000; 38: 3515-3517.

15. Woo PCY, Leung PKL, Leung KW, Yuen KY. Identification by 16S ribosomal RNA gene sequencing of an Enterobacteriaceae species from a bone marrow transplant recipient. $J$ Clin Pathol: Mol Pathol 2000; 53: 211-215.

16. Woo PCY, Fung AMY, Wong SSY, Tsoi H-W, Yuen K-Y. Isolation and characterization of a Salmonella enterica serotype Typhi variant and its clinical and public health implications. J Clin Microbiol 2001; 39: 1190-1194.

17. Woo PCY, Chong KT, Leung K, Que T, Yuen K. Identification of Arcobacter cryaerophilus isolated from a traffic accident victim with bacteremia by ribosomal RNA gene sequencing. Diagn Microbiol Infect Dis 2001; 40: 125-127.

18. Cheuk W, Woo PCY, Yuen KY, Yu PH, Chan JKC. Intestinal inflammatory pseudotumour with regional lymph node involvement: identification of a new bacterium as the aetiological agent. J Pathol 2001; 192: 289-292.

19. Luk W-K, Wong SSY, Yuen K-Y et al. Inpatient emergencies encountered by an infectious disease consultative service. Clin Infect Dis 1998; 26: 695-701.

20. Murray PR, Baron EJ, Pfaller MA, Tenover FC, Yolken RH (eds). Manual of clinical microbiology, 7th edn. Washington, DC, ASM Press. 1999.

21. Woo PC, Lo CY, Lo SK et al. Distinct genotypic distributions of cytomegalovirus (CMV) envelope glycoprotein in bone marrow and renal transplant recipients with CMV disease. Clin Diagn Lab Immunol 1997; 4: 515-518.

22. Thompson JD, Higgins DG, Gibson TJ. CLUSTAL W: improving the sensitivity of progressive multiple sequence alignment through sequence weighting, position-specific gap penalties and weight matrix choice. Nucleic Acids Res 1994; 22: $4673-4680$.

23. International Journal of Systematic Bacteriology. Announcement of the valid publication of new names and new combinations previously effectively published outside the IJSB. List no. 1. Int J Syst Bacteriol 1977; 27: 306.

24. Megraud F, Bebear C, Dabernat H, Delmas C. Haemophilus species in the human gastrointestinal tract. Eur $J$ Clin Microbiol Infect Dis 1988; 7: 437-438.

25. Palmer GG. Haemophili in faeces. J Med Microbiol 1981; 14: $147-150$.

26. Dewhirst FE, Paster BJ, Olsen I, Fraser GJ. Phylogeny of 54 representative strains of species in the family Pasteurellaceae as determined by comparison of $16 \mathrm{~S}$ rRNA sequences. J Bacteriol 1992; 174: 2002-2013.

27. Potts TV, Zambon JJ, Genco RJ. Reassignment of Actinobacillus actinomycetemcomitans to the genus Haemophilus as Haemophilus actinomycetemcomitans comb. nov. Int $J$ Syst Bacteriol 1985; 35: 337-341. 